\title{
Penggunaan Campur Kode dalam Komunikasi Santri di Pondok Pesantren Anwarul Huda Malang
}

\author{
Mochamad Arifin Alatas ${ }^{\mathrm{a}, 1^{*}}$, Irma Rachmayanti ${ }^{\mathrm{b}, 2}$, \\ a Institut Agama Islam Negeri Madura, Jalan Raya Panglegur KM.4, Pamekasan, Indonesia, 69371 \\ b Universitas Islam Negeri Maulana Malik Ibrahim Malang, Jalan Gajayana No. 50, Malang, Indonesia, 65144 \\ ${ }^{1}$ marifin@iainmadura.ac.id*; 2 irmarachmayanti91@gmail.com \\ * Corresponding Author
}

\begin{tabular}{ll}
\hline INFO ARTIKEL & ABSTRAK \\
\hline Sejarah Artikel: & Penelitian ini dilatarbelakangi adanya fenomena campur kode dalam \\
Diterima: 12 Maret 2020 & komunikasi santri. Adapun penelitian ini bertujuan untuk mendeskripsikan \\
Direvisi: 15 Maret 2020 & campur kode yang terjadi di Pondok Pesantren Anwarul Huda Malang \\
Disetujui: 23 Maret 2020 & (PPAH). Penelitian ini menggunakan metode penelitian deskriptif kualitatif. \\
Tersedia Daring: 12 April & Metode pengumpulan data dengan observasi langsung. Peneliti melakukan \\
2020 & pengamatan langsung di PPAH. Sumber data penelitian ini adalah \\
\hline Kata Kunci: & komunikasi sehari-hari di PPAH. Pengumpulan data dilakukan dengan \\
Campur kode & menyimak, merekam, dan mencatat komunikasi sehari-hari santri. Teknik \\
Komunikasi & analisis data menganalisis data rekaman dan catatan dengan melihat \\
Santri & konteks, latar belakang, siapa, asal, dan peran penutur saat bertutur. Hasil \\
& penelitian adalah: Wujud campur kode yang meliputi (1) Jawa-Arab, (2) \\
& Indonesia-Jawa, (3) Jawa-Indonesia. Bentuk campur kode santri PPAH \\
& meliputi (1) terdapat penyisipan kata, (2) terdapat penyisipan frasa, (3) \\
& terdapat penyisipan ungkapan atau idiom, dan (4) terdapat penyisipan \\
& baster. Berdasarkan tipe campur kode di PPAH meliputi (1) campur kode ke \\
& dalam atau inner code-mixing dan (2) campur kode ke luar atau outer code- \\
& mixing.
\end{tabular}

\begin{tabular}{ll}
\hline ABSTRACT \\
\hline $\begin{array}{l}\text { Keywords: } \\
\text { Mix Code }\end{array}$ & This research is motivated by the phenomenon of code mixing in the \\
Santri & communication of students. The purpose of this research is to describe the \\
& code mix that occurs in Anwarul Huda Islamic Boarding School Malang \\
& (PPAH). This research uses descriptive qualitative research methods. Data \\
& collection method with direct observation. Researchers make direct \\
& observations on PPAH. The data source of this research is daily \\
& communication at PPAH. Data collection is done by listening, recording and \\
recording the daily communication of students. Data analysis techniques \\
analyze recorded data and records by looking at the context, background, who, \\
origin, and role of the speaker when speaking. The results of the studyare: The \\
form of mixed code which includes (1) Javanese-Arabic, (2) Indonesian- \\
Javanese, (3) Javanese-Indonesian. The mixed forms of PPAH santri code \\
include (1) there is insertion of words, (2) there is insertion of phrases, (3) \\
there is insertion of expressions or idioms, and (4) there is insertion of baster. \\
Based on the type of code mixing in PPAH, it includes (1) mixing code into or \\
inner code-mixing and (2) mixing code outside or outer code-mixing.
\end{tabular}

(C) 2020, Alatas \& Rachmayanti This is an open access article under CC-BY license (c) (i) (?) 
How to Cite: Alatas, M. A., \& Rachmayanti, I. (2020). Penggunaan Campur Kode dalam Komunikasi Santri di Pondok Pesantren Anwarul Huda Malang. JURNAL SATWIKA, 4 (1), 34-46. doi: https://doi/org/10.22219/SATWIKA.Vol4.No1.43-55

\section{Pendahuluan}

Pondok pesantren merupakan salah satu Lembaga Pendidikan Islam. Adapun unsur dasar pondok pesantren sesuai dengan Zamakhsyari Dhofier yang menyebutkan bahwa elemen dasar pondok pesantren meliputi pondok, masjid, santri, pembelajaran kitab-kitab klasik, dan kiai (Mansur, 2013). Komunikasi yang terjadi dalam pondok pesantren memiliki ciri khas tersendiri. Hal tersebut dipengaruhi oleh beberapa faktor, yaitu lingkungan pondok pesantren, proses pembelajaran, latar belakang dan budaya santri, serta kiai.

Pondok Pesantren Anwarul Huda (PPAH) merupakan pondok pesantren salafiyah. Maksud salafiyah adalah menggunakan program pendidikan agama tradisional. Hal tersebut terlihat pada pengajaran kitab-kitab klasik atau kitab-kitab kuning. Kitab-kitab kuning tersebut berbahasa Arab dan dimaknai dengan bahasa Jawa halus (krama). Apabila pemaknaan dalam bahasa Jawa kesulitan maka terkadang dijelaskan dalam bahasa Indonesia. Metode yang digunakan mempertahankan metode tradisional. Metode tersebut pada umumnya dilakukan dengan ustadz memaknai kitabkitab kuning di depan kelas dan santri mencatat dengan huruf Arab-Jawa (pegon).

PPAH beralamat di Kelurahan Karangbesuki, Kecamatan Sukun, Kota Malang. Santri dalam PPAH pada umumnya adalah mahasiswa dan siswa. Peneliti telah lima tahun hidup di lingkungan Pondok Pesantren Anwarul Huda Malang (PPAH). Selama lima tahun terakhir, peneliti aktif berkomunikasi di lingkungan pondok. Hal yang menarik dalam komunikasi ini adalah banyaknya jumlah santri dengan berbagai latar belakang bahasa yang berbeda. Selain itu bahasa yang dipelajari adalah bahasa Arab melalui kitab-kitab kuning yang dimaknai dengan bahasa Jawa. Hal menarik lainnya adalah banyak bahasa daerah yang digunakan di lingkungan Pondok.
Bahasa pondok memiliki ciri khas sendiri. Sesuai dengan pendapat Nababan (1984:1) bahwa ciri khas yang paling manusiawi adalah bahasanya. Bahasa adalah satu-satunya milik manusia yang tidak pernah lepas dari segala kegiatan dan gerak manusia sepanjang keberadaan manusia itu, sebagai makhluk yang berbudaya dan bermasyarakat (Horwae, 2018).

Berdasarkan pendapat tersebut, santri PPAH merupakan santri yang bilingual. Bilingual merupakan penggunaan dua bahasa atau lebih dalam berkomunikasi sehari-hari (Keraf, 1984). Meldani (2018) juga menjelaskan bahwa kemampuan berbicara lebih dari satu bahasa dikenal dengan istilah kedwibahasaan atau bilingualism. Fishman (dalam Simatupang, Rohmadi, \& Saddhono, 2018a) menyatakan bahwa who speaks what language to whom and when. Kridalaksana (dalam Murniati, 2015), menjelaskan bahwa kedwibahasaan adalah penggunaan dua bahasa atau lebih oleh seseorang atau oleh suatu masyarakat.

Santri PPAH memaknai kitab kuning (bahasa Arab) dengan bahasa Jawa halus. Santri PPAH pada umumnya juga menggunakan bahasa Jawa dalam berkomunikasi, tetapi kadang-kadang menggunakan bahasa Indonesia. Bahkan, santri PPAH juga menggunakan bahasa Arab dan bahasa Inggris. Hal tersebut sesuai dengan pendapat Abdul Chaer and Agustina (2010:154) bahwa bahasa Indonesia terdiri atas (1) bahasa Indonesia, (2) bahasa daerah, dan (3) bahasa asing.

Bilingualisme berkaitan erat dengan campur kode. Seorang bilingualisme merupakan awal penyebab terjadinya campur kode dalam bahasa. Campur kode adalah suatu peristiwa kebahasaan. Hal tersebut terjadi karena kontak bahasa. Pada umumnya campur kode ini terjadi pada masyarakat bilingual atau memiliki dua bahasa atau lebih. 
Santri PPAH merupakan santri yang tinggal di PPAH. Santri tersebut tinggal dan hidup bersama. Santri tersebut juga berasal dari daerah yang berbeda dan bahasa yang berbeda-beda. Mayoritas santri PPAH berasal dari daerah Jawa, adapula dari Madura, Banyuwangi, dan bahkan ada dari luar Pulau Jawa. Bahasa interaksi komunikasi sehari-hari adalah bahasa Jawa. Hal tersebut karena mayoritas berasal dari Jawa, sedangkan bahasa kedua yang digunakan santri dalam komunikasi seharihari adalah bahasa Indonesia, Arab, dan Inggris. Dengan demikian santri PPAH terdiri atas berbagai bahasa dan budaya. Hal tersebut selaras dengan pendapat Kustriyono (2016), bahwa alih kode dan campur kode selalu melekat pada kehidupan sehari-hari terutama dalam percakapan dengan orang lain.

Pembelajaran di pondok umumnya menggunakan bahasa Jawa (B1). Penggunaan bahasa Jawa (B1) tersebut dicampur dengan bahasa Indonesia, Arab, dan Inggris (B2). Hal tersebut karena ketika berkomunikasi sehari-hari santri menggunakan bahasa Jawa, ketika memaknai kitab kuning santri menggunakan Jawa halus, ketika berdiskusi santri menggunakan bahasa Indonesia, ketika memaknai Al-Quran santri menggunakan bahasa Arab, dan ada pula diskusi dengan bahasa Inggris. Dengan demikian, berbagai bahasa digunakan dalam komunikasi santri di PPAH. Bahasa tersebut mengakibatkan adanya penyisipan bahasa Indonesia ke Arab dan sebaliknya. Penyisipan pun terjadi dalam bahasa Jawa ke bahasa Indonesia dan sebaliknya

Peran santri PPAH juga mempengaruhi penggunaan bahasa sehari-hari. Penggunaan bahasa santri dengan Kiai secara umum menggunakan bahasa Jawa halus (Krama Inggil), santri dengan keluarga Kiai (Gus dan Neng) juga menggunakan bahasa Jawa halus (Krama Inggil), santri dengan ustad secara umum juga krama inggil dan krama, sedangkan santri dengan santri menggunakan bahasa Jawa ngoko.

Terdapat penelitian terdahulu yang relevan dengan penelitian ini. Penelitian yang dilakukan oleh Isnaini (2014) serta Kurniasih and Zuhriyah (2017) yang meneliti mengenai wujud campur kode, bentuk campur kode. Adapun hasil penelitian tersebut menunjukkan bahwa dalam perkacapan santri di Pondok Pesantren terjadi campur kode dan alih kode berupa bahasa Jawa dan bahasa Indonesia karena ketidakefektifan penggunaan bahasa asing oleh santri.

Perbedaan penelitian ini dengan penelitian sebelumnya adalah (1) sumber data yang berbeda, yakni santri PPAH Kota Malang, (2) penelitian ini juga menganalisis fungsi campur kode berkaitan dengan pendidikan karakter santri, (3) berdasarkan tipe campur kode di PPAH meliputi (1) campur kode ke dalam dan (2) campur kode ke luar dan (4) faktor munculnya campur kode tidak hanya ketidakefektifan penggunaan bahasa asing oleh santri, melainkan juga peran santri, daerah asal, bahasa pertama dan kedua, dan konteks komunikasi santri.

Ilmu yang mengkaji fenomena komunikasi sehari-hari adalah kajian sosiolinguistik. Hal tersebut sesuai dengan pendapat Nugroho (2011) bahwa sosiolinguistik merupakan kajian bahasa yang berkaitan dengan kondisi dan komunikasi di masyarakat. Kajian sosiolinguistik tersebut digunakan dalam menganalisis fenomena campur kode yang terjadi dalam bahasa komunikasi sehari-hari santri. Kajian sosiolinguistik menitikberatkan pada bahasa komunikasi yang dihubungkan dengan latar belakang yang mengatakan. Hal tersebut sesuai dengan pendapat Meyerhoff (2007) bahwa sosiolinguistik mengkaji fenomena bahasa secara sistematis yang berhubungan dengan latar belakang pembicara.

Campur kode merupakan kode utama atau dasar yang digunakan, memiliki fungsi, dan otonomi, sedangkan kode lain hanya serpihan-serpihan tanpa fungsi atau keotonomian sebagai sebuah kode (A Chaer, 2006). Hymes (dalam Agustinuraida, 2017) menyatakan campur kode terjadi pada antarbahasa, antar-ragam dan gaya bahasa. Kridalaksana (dalam Bintara, Saddhono, \& 
Purwadi, 2017) menegaskan bahwa campur kode ialah penggunaan suatu unsur kebahasaan dari satu bahasa ke bahasa lain dengan tujuan untuk menambah gaya atau ragam bahasa. Hudson (dalam Nirmala, 2013) mendefinisikan campur kode atau mixing code yaitu "...where a fluent bilingual talking to another fluent bilingual changes language without any chage all in the situation. This kind of alternation is called code mixing." Sependapat dengan hal tersebut, Kahcru (dalam Hapsari, 2018) berpendapat campur kode merupakan penggunaan dua unsur bahasa atau lebih dengan saling memasukkan unsur-unsur bahasa yang satu ke dalam bahasa yang lain secara konsisten.

Campur kode bukanlah bentuk kesalahan berbahasa yang disebabkan lemahnya penguasaan penutur terhadap bahasa yang digunakan (Rohmani, Fuady, \& Anindyarini, 2013). Kesalahan berbahasa bisa terjadi karena adanya banyak hal, misalnya pengaruh bahasa ibu, kekurangpahaman pemakai bahasa terhadap bahasa yang dipakainya, dan pengajaran bahasa yang kurang sempurna (Setyawati dalam Saddhono, 2012). Campur kode terjadi secara tidak sadar atau tidak sengaja (Subroto dalam Simatupang, Rohmadi, \& Saddhono, 2018b).

Dengan demikian, penelitian berjudul Penggunaan Campur Kode dalam Komunikasi Santri di Pondok Pesantren Anwarul Huda Malang ini bertujuan untuk mendeskripsikan fenomena campur kode dalam bahasa komunikasi santri Pondok Pesantren Anwarul Huda. Hal tersebut diperinci meliputi wujud campur kode, bentuk campur kode, dan fungsi campur kode dalam bahasa komunikasi santri Pondok Pesantren Anwarul Huda.

\section{Metode}

Penelitian ini menggunakan metode penelitian deskriptif kualitatif. Metode tersebut bertujuan untuk mendeskripsikan, menggambarkan, dan menginterpretasikan objek penelitian dengan apa adanya. Hal tersebut selaras dengan pendapat Chariri
(2009:9) bahwa penelitian kualitatif adalah penelitian yang mengungkap sebuah keadaan apa adanya. Penelitian ini dilakukan di Pondok Pesantren Anwarul Huda Malang Jl. Raya Candi III no 454 Karang Besuki Malang. Peneliti melakukan pengamatan langsung di PPAH. Sumber data dalam penelitian ini adalah campur kode dalam bahasa komunikasi sehari-hari santri PPAH.

Instrumen penelitian dalam penelitian ini menggunakan manusia sebagai instrumen utama. Instrumen utama tersebut yaitu peneliti sendiri yang dipandu dengan intrumen pengambilan data, instrumen kodifiaksi data, dan instrumen analisis data. Pengumpulan data dalam penelitian ini dengan metode observasi langsung. Hal tersebut dilakukian dengan menyimak, merekam, dan mencatat komunikasi seharihari santri di PPAH. Peneliti dating langsung dan kadang terlibat dan kadang tidak terlibat dalam percakapan. Keterlibatan peneliti tersebut semata-mata untuk memancing fenomena campur kode (Sugiyono, 2011).

Peneliti juga melakukan wawancara tidak berstruktur yakni wawancara bebas dengan tidak menggunakan pedoman wawancara yang tersusun sistematis dan lengkap. Wawancara tersebut dilakukan kepada santri, ustaz, dan keluarga kiai yang ada di PPAH. Alasan pemilihan informan yang diwawancarai untuk mencari latar belakang santri, ustaz, dan keluarga kiai yang telah direkam komunikasi sehari-hari.

Data penelitian ini berupa wujud campur kode, bentuk campur kode, dan fungsi campur kode. Adapun data tersebut terdiri atas kutipan komunikasi sehari-hari santri PPAH. Data penelitian kualitatif berupa rekaman dan catatan komunikasi sehari-hari santri PPAH.

Teknik analisis data dilakukan dengan menganalisis data rekaman dan catatan dengan melihat konteks, latar belakang, siapa, asal, dan peran penutur saat bertutur. Secara teknis analisis data penelitian ini terdiri atas tiga bagian yakni (1) analisis wujud campur kode, (2) analisis bentuk campur kode, dan (3) analisis fungsi campur kode. 


\section{Hasil dan Pembahasan}

\subsection{Wujud Campur Kode}

Wujud campur kode yang digunakan santri PPAH meliputi bahasa Jawa, Indonesia, Arab, dan Inggris. Adapun wujudnya meliputi Jawa-Arab, Arab-Jawa, Jawa-Indonesia, dan Indonesia-Jawa. Campur kode Jawa-Arab dapat dilihat pada kutipan berikut.

\author{
Kutipan 1. Percakapan Campur Kode Jawa- \\ Arab \\ Santri 1: "Cak, Ustad Darsono napa wonten?" \\ (Apakah Pak Darsono ada?) \\ Santri 2: "Gak ngerti aku cak" \\ (Tidak tahu) \\ Santri 1: "Jarene, Ustad iku paling galak cak?" \\ (Katanya, Bapak itu galak?) \\ Santri 2: "Iyo Cak, Ustad Darsono iku mustahiq \\ paling galak." \\ (Iya, beliau galak)
}

Berdasarkan kutipan 1 tersebut, bahasa yang digunakan oleh santri 1 adalah bahasa Jawa dan Arab yakni ketika bertanya Ustaz Darsono napa wonten. Santri 2 pun menjawab dengan bahasa Jawa yakin dengan berkata Gak ngerti aku. Penggunaan bahasa tersebut merupakan penggunaan campur kode Jawa-Arab.

Campur kode yang terjadi dalam kutipan 1 merupakan campur kode Jawa-Arab. Hal tersebut dibuktikan dengan munculnya kata mustahiq. Campur kode tersebut termasuk campur kode keluar atau uter code-mixing. Hal tersebut karena kata mustahiq berbeda secara politis. Maksudnya adalah antara tidak adanya hubungan kekerabatan baik secara geografis dan politis. Suwito (1983:76) menjelaskan bahwa campur kode keluar adalah campur kode yang berbeda antara bahasa sumber dan bahasa sasaran. Wujud campur kode tersebut adalah sama-sama asing antara bahasa sumber dan bahasa dituju, yakni bahasa Jawa-Arab. Temuan dalam kutipan 1 tersebut sesuai dengan penelitian terdahulu oleh Isnaini (2014) yang menyebutkan adanya campur kode ke-dalam. Hanya saja bedanya adalah ini antara bahasa Jawa dan Arab.
Adapun faktor munculnya campur kode karena istilah tersebut efektif digunakan dalam komunikasi. Efektif berarti santri 1 dan santri 2 saling memahami. Hal tersebut berbeda dengan penelitian sebelumnya yang menyatakan campur kode karena ketidakefektifan penggunaan bahasa asing oleh santri. Selain Jawa-Arab, wujud campur kode juga dapat dilihat pada bahasa Indonesia-Jawa. Hal tersebut dapat dilihat pada kutipan berikut.

\section{Kutipan 2. Percakapan Campur Kode Indonesia-Jawa \\ Santri 1: "Cak, sudah sholat? Bangun-bangun." Santri 2: "Iya cak." \\ Santri 1: "Sudah jam 5 cak. Engko telat lho?" (Sudah jam 5. Nanti telat) \\ Santri 2: "Iya cak. Sebentar lagi cak" \\ Santri 1: "Yo wes ndang tangi gek sholat!" (ya sudah, cepet bangun dan sholat!)}

Berdasarkan kutipan 2, terlihat campur kode bahasa Jawa dalam bahasa Indonesia. Hal tersebut terlihat pada Santri 1 yang membangunkan dan bertanya sudah salat. Santri 2 merespon dengan menjawab "Iya Cak". Campur kode Indonesia dan Jawa juga terlihat pada Santri 1 yang menanyakan "Sudah jam 5 cak" dilanjutkan dengan bahasa Jawa "Engko telat lho". Dilanjutkan dengan Santri 1 yang sekali lagi memperingatkan dengan bahasa Jawa "Yo wes ndang tangi gek sholat!".

Campur kode yang terjadi dalam kutipan 2 tersebut merupakan campur kode ke-dalam atau inner code-mixing. Hal tersebut karena antara bahasa Indonesia dan bahasa Jawa masih ada kekerabatan. Suwito menjelaskan peristiwa tersebut merupakan hubungan yang bersifat vertikal (Suwito, 1983).

Selain hal tersebut, antara bahasa Indonesia dan bahasa Jawa masih memiliki hubungan secara geografis dan politis. Hubungan tersebut yakni di dalam masyarakat Indonesia dikenal bahasa daerah. Salah satu bahasa daerah adalah bahasa Jawa. Dengan demikian dapat disimpulkan bahwa kutipan 2 tersebut merupakan campur kode ke-dalam atau inner code-mixing. 
Campur kode juga terjadi antara bahasa Jawa dengan bahasa Indonesia. Campur kode tersebut dapat dilihat pada kutipan berikut.

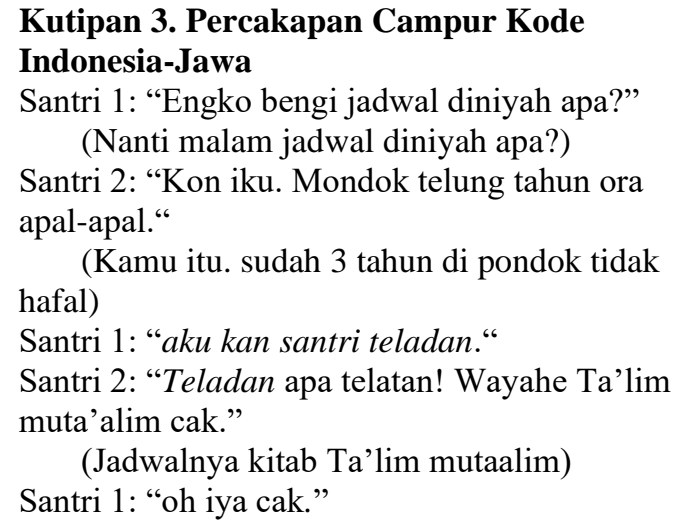

Berdasarkan kutipan 3, terlihat adanya campur kode antara bahasa Jawa dengan bahasa Indonesia. Hal tersebut dapat dilihat ketika Santri 1 bertanya jadwal diniyah dengan bahasa Jawa. Santri 2 menjawab dengan mengejek menggunakan bahasa Jawa. Setelah itu Santri 1 mengatakan santri teladan yang merupakan bahasa Indonesia. Ssantri 2 pun membalasnya dengan bahasa Indonesia, yakni teladan apa telatan.

Berdasarkan kutipan 3 tersebut, jenis campur kode yang terjadi adalah campur kode ke-dalam atau inner code-mixing. Hal tersebut karena bahasa sumbernya adalah bahasa Jawa dan bahasa sasarannya adalah bahasa Indonesia. Antara bahasa Jawa dan bahasa Indonesia memiliki kekerabatan, yakni bahasa Jawa sebagai bahasa daerah, sedangkan bahasa Indonesia sebagai bahasa nasional. Hubungan tersebut merupakan hubungan bersifat vertikal (Suwito, 1983:76). Dengan demikian kutipan 3 merupakan percakapan komunikasi santri PPAH dengan jenis campur kode ke dalam atau inner code-mixing.

Campur kode yang terjadi dalam komunikasi santri PPAH terdapat campur kode keluar atau uter code-mixing. Antara tidak adanya hubungan kekerabatan baik secara geografis dan politis. Suwito (1983:76) menjelaskan bahwa campur kode keluar adalah campur kode yang berbeda antara bahasa sumber dan bahasa sasaran. Wujud campur kode tersebut adalah sama- sama asing antara bahasa sumber dan bahasa yang dituju, yakni bahasa Jawa-Arab.

Campur kode dalam komunikasi santri PPAH juga terjadi pada bahasa Jawa dalam bahasa Indonesia. Campur kode tersebut merupakan campur kode ke dalam atau inner code-mixing. Hal tersebut karena antara bahasa Indonesia dan bahasa Jawa masih ada kekerabatan. Suwito (1983:76) menjelaskan peristiwa tersebut merupakan hubungan yang bersifat vertikal.

Selain hal tersebut, antara bahasa Indonesia dan Bahasa Jawa masih memiliki hubungan secara geografis dan politis. Hubungan tersebut yakni di dalam masyarakat Indonesia dikenal bahasa daerah. Salah satu bahasa daerah adalah bahasa Jawa. Dengan demikian dapat disimpulkan bahwa hal tersebut merupakan campur kode ke dalam atau inner code-mixing.

Campur kode dalam komunikasi santri PPAH juga muncul antara bahasa Jawa dengan bahasa Indonesia. Jenis campur kode yang terjadi adalah campur kode ke dalam atau inner code-mixing. Hal tersebut karena bahasa sumbernya adalah bahasa Jawa dan bahasa sasarannya adalah bahasa Indonesia. Antara bahasa Jawa dan bahasa Indonesia memiliki kekerabatan yakni bahasa Jawa sebagai bahasa daerah, sedangkan bahasa Indonesia sebagai bahasa Nasional. Hubungan tersebut merupakan hubungan bersifat vertikal.

Faktor dominan yang melatarbelakangi peristiwa campur kode dalam data di atas, yaitu a) latar belakang sikap: hal ini berhubungan dengan karakteristik penutur, seperti latar sosial dan tingkat pendidikan yang dimiliki. Bahasa ibu sangat mempengaruhi ucapan siswa di sekolah (Saddhono \& Rohmadi, 2014).

\subsection{Bentuk Campur Kode}

Bentuk campur kode yang dilakukan santri PPAH berdasarkan struktur kebahasaan meliputi (1) penyisipan dalam bentuk kata, (2) penyisipan dalam bentuk frasa, (3) penyisipan dalam bentuk ungkapan atau idiom, dan (4) penyisipan dalam bentuk baster. 
Penyisipan dalam bentuk kata, dapat dilihat pada kutipan berikut.

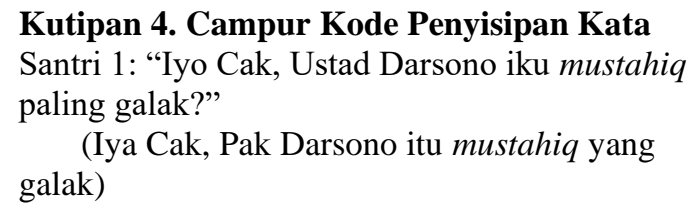

Berdasarkan kutipan 4 terlihat penyisipan dalam bentuk kata. Penyisipan tersebut ketika santri 1 menyisipkan kata Mustahiq. Santri 1 sebelumnya meggunakan bahasa Jawa dan kemudian menyisipkan bahasa Arab.

Kutipan 4 menunjukkan penggunaan kata "mustahiq". Mustahiq berarti orang yang memiliki hak. Berdasarkan konteks, Mustahiq merupakan seorang guru/ustadz yang mengajar di kelas tertentu. Pada umumnya mustahiq membawahi 20 santri. Mustahiq berbeda dengan guru yang mengajar pelajaran. Seorang Mustahiq memiliki hak untuk menaikkan santri dan tidak menaikkan santri. Naik dan tidaknya santri tersebut berdasakan nilai, sikap, dan tingkah laku santri

Penyisipan bentuk frasa, dapat dilihat pada kutipan berikut.

\footnotetext{
Kutipan 5. Campur Kode Penyisipan Frasa

Santri 1: "Haflatul Imtihan mene a?" (Haflatul Imtihan besok ya?)

Santri 2: "Enggeh cak. Yai Baidowi Muslich ngisi cak."

(Iya Cak. Kyai Baidowi Muslich hadir cak.)
}

Berdasarkan kutipan 5 terlihat penyisipan dalam bentuk frasa. Penyisipan tersebut yakni ketika santri 1 menyisipkan frasa Haflatul Imtihan. Frasa tersebut merupakan frasa dalam bahasa Arab. Kemudian dilanjutkan berkomunikasi dengan bahasa Jawa.

Berdasarkan kutipan 5, terlihat ada penyisipan frase yakni "Haflatul Imtihan". Haflatul Imtihan merupakan istilah untuk wisuda bagi santri pondok. Kegiatan tersebut pada umumnya terdiri atas berbagai macam rangkaian kegiatan. Kegiatan Haflatul Imtihan ditutup dengan pengajian akbar yang dihadiri Kiai besar. Dengan demikian, kutipan 5 merupakan bentuk penyisipan frasa dalam campur kode.

Penyisipan bentuk baster, dapat dilihat pada kutipan berikut.

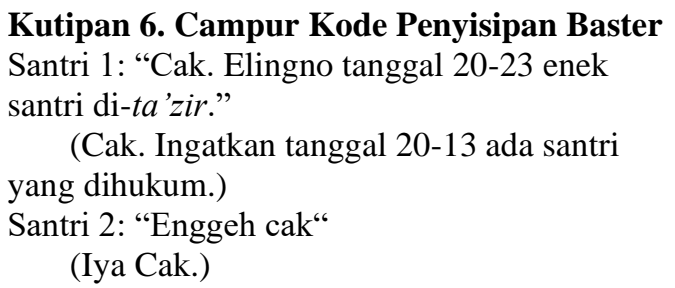

Berdasarkan kutipan 6 terlihat penyisipan dalam bentuk baster. Bentuk baster merupakan bentuk gabungan antara dua bahasa atau lebih yang dijadikan dalam satu kata. Campur kode terjadi ketika Santri 1 menggunakan bahasa Jawa dan kemudian bahasa Arab yakni di-ta'zir.

Berdasarkan kutipan 6, terlihat campur kode penyisipan baster yakni "di-ta'zir". Ta'zir memiliki arti hukum. Hal tersebut merupakan bentuk baster yang merupakan gabungan bahasa Indonesia dan bahasa Arab. "di-ta'zir" terdiri atas awalan di dan kata dasar ta'zir. Awalan di tersebut merupakan bahasa Indonesia. sedangkan kata ta'zir merupakan kata dalam bahasa Arab. Kata dita'zir memiliki makna hukuman pada santri yang melanggar aturan pondok (bolos diniyah dan tidak tidur pondok). Dengan demikian kutipan 6 tersebut merupakan campur kode dalam bentuk baster dalam komunikasi santri PPAH.

\section{Penyisipan bentuk idiom atau ungkapan,} dapat dilihat pada kutipan berikut.

Kutipan 7. Campur Kode Penyisipan Idiom

Santri 1: "Roan Jum'at bersih resik-resik kantor cak."

(Kerja bakti Jumat bersih bersih-bersih kantor.)

Santri 2: "Lho? Roan Jum'at bersih wis diumumne ta?"

(Kerja bakti Jum'at bersih apakah sudah diumumkan?)

Santri 1: "Uwis Cak. Kamar A-9 resik-resik kantor ngarep."

(Sudah Cak. Kamar A-9 membersihkan kantor depan.) 
Santri 2: "oww... enggeh cak."

(Iya Cak)

Berdasarkan kutipan 7 tersebut terlihat campur kode bahasa jawa, indonesia, dan arab. Hal tersebut terlihat pada Santri 1 yang menggunakan bahasa jawa dan indonesua yakni Roan Jum 'at bersih resik-resik kantor. Begitu juga dengan respon oleh Santri 2 yang menggunakan campur kode antara bahasa jawa dan indonesia

Berdasarkan kutipan 7, terlihat campur kode dalam bentuk penyisipan idiom atau ungkapan yakni “Jum'at Bersih". Jum'at bersih merupakan ungkapan kegiatan rutin kerja bakti PPAH untuk bersama-sama membersihkan pondok. Jum'at bersih para santri dibagi berdasarkan kamar untuk membersihkan tempat-tempat tertentu di dalam pondok. Sehingga pondok menjadi lebih bersih dan sehat.

Bentuk campur kode yang dilakukan santri PPAH berdasarkan struktur kebahasaan meliputi (1) penyisipan dalam bentuk kata, (2) penyisipan dalam bentuk frasa, (3) penyisipan dalam bentuk ungkapan atau idiom, dan (4) penyisipan dalam bentuk baster. Hal tersebut diperinci sebagai berikut.

Bentuk campur kode dalam komunikasi santri adalah terdapat bentuk kata. Penggunaan kata "mustahiq". Mustahiq berarti orang yang memiliki hak. Berdasarkan konteks, Mustahiq merupakan seorang guru/ustaz yang mengajar di kelas tertentu. Pada umumnya mustahiq membawahi 20 santri. Mustahiq berbeda dengan guru yang mengajar pelajaran. Seorang Mustahiq memiliki hak untuk menaikkan santri dan tidak menaikkan santri. Naik dan tidaknya santri tersebut berdasakan nilai, sikap, dan tingkah laku santri

Bentuk campur kode dalam komunikasi santri juga terlihat penyisipan dalam bentuk frasa. Penyisipan tersebut yakni ketika santri 1 menyisipkan frasa Haflatul Imtihan. Frasa tersebut merupakan frasa dalam bahasa Arab. Kemudian dilanjutkan berkomunikasi dengan bahasa Jawa. Terlihat ada penyisipan frase yakni "Haflatul Imtihan". Haflatul Imtihan merupakan istilah untuk wisuda bagi santri pondok. Kegiatan tersebut pada umumnya terdiri atas berbagai macam rangkaian kegiatan. Kegiatan Haflatul Imtihan ditutup dan diakhiri dengan pengajian akbar yang dihadiri Kyai besar. Dengan demikian bentuk campur kode dalam komunikasi santri yakni penyisipan frasa.

Bentuk campur kode dalam komunikasi santri juga terlihat penyisipan dalam bentuk baster. Bentuk baster merupakan bentuk gabungan antara dua bahasa atau lebih yang dijadikan dalam satu kata. Campur kode terjadi ketika Santri 1 menggunakan bahasa Jawa dan kemudian bahasa Arab yakni dita'zir.

Bentuk campur kode dalam komunikasi santri juga terlihat campur kode penyisipan baster yakni "di-ta'zir". Ta'zir memiliki arti hukum. Hal tersebut merupakan bentuk baster yang merupakan gabungan bahasa Indonesia dan bahasa Arab. "di-ta'zir" terdiri atas awalan di dan kata dasar ta'zir. Awalan di tersebut merupakan bahasa Indonesia. sedangkan kata ta'zir merupakan kata dalam bahasa Arab. Kata di-ta'zir memiliki makna hukuman pada santri yang melanggar aturan pondok (bolos diniyah dan tidak tidur pondok).

Bentuk campur kode dalam komunikasi santri juga terlihat campur kode bahasa jawa, indonesia, dan arab. Hal tersebut terlihat pada penggunaan bahasa jawa dan indonesua yakni Roan Jum'at bersih resik-resik kantor. Begitu juga dengan respon menggunakan campur kode antara bahasa Jawa dan Indonesia

Bentuk campur kode dalam komunikasi santri juga terdapat penyisipan idiom atau ungkapan, yakni “Jum'at Bersih". Jum'at bersih merupakan ungkapan kegiatan rutin kerja bakti PPAH untuk bersama-sama membersihkan pondok. Jum'at bersih para santri dibagi berdasarkan kamar untuk membersihkan tempat-tempat tertentu di dalam pondok sehingga pondok menjadi lebih bersih dan sehat.

\subsection{Fungsi Campur Kode}

Campur kode memiliki beberapa fungsi. Berdasarkan paparan di atas, fungsi campur 
kode oleh santri PPAH meliputi (1) Fungsi ketepatan makna atau rasa, (2) fungsi argumentatif, (3) fungsi persuasif, (4) fungsi singkat dan mudah diucapkan, (5) fungsi sopan dan santun, dan (6) fungsi komunikatif.

Ketepatan rasa (makna), dapat dilihat pada kutipan berikut.

\section{Kutipan 8. Campur Kode Ketepatan Rasa (Makna) \\ Santri 1: "Haflatul Imtihan mene a?" (Haflatul Imtihan besok ya?) \\ Santri 2: "Enggeh cak. Yai Baidowi Muslich ngisi cak." \\ (Iya Cak. Kyai Baidowi Muslich hadir cak.)}

Berdasarkan kutipan 8, terlihat adanya ketepatan rasa (makna) yakni "Haflatul Imtihan". Haflatul Imtihan merupakan istilah untuk wisuda bagi santri pondok. Kegiatan tersebut pada umumnya terdiri atas berbagai macam rangkaian kegiatan. Kegiatan Haflatul Imtihan ditutup dan diakhiri dengan pengajian akbar yang dihadiri Kyai besar.

Haflatul Imtihan juga merupakan sarana untuk menguatkan pendidikan karakter. Hal tersebut karena dalam kegiatan tersebut secara tidak langsung santri diajarkan untuk memiliki karakter melalui kearifan local PPAH. Hal tersebut seuai dengan pendapat Iswatiningsih yang menyatakan bahwa penguatan pendidikan karakter dapat dilakukan melalui pendidikan budaya berkearifan lokal (Iswatiningsih, 2019).

Hal tersebut menunjukkan adanya ketepan rasa (makna) karena istilah tersebut hanya ada dalam dunia pesantren. Istilah tersebut mirip dengan wisuda di pendidikan formal. Hanya saja dalam isitlah tersebut terdiri atas berbagai macam kegiatan baik edukasi maupun lomba-lomba dan diakhiri dengan pengajian. Tidak ada istilah lain yang menyamai dengan Haflatul Imtihan. Dengan demikian campur kode memiliki fungsi ketepatan rasa (makna).

Lebih argumentatif, dapat dilihat pada kutipan berikut.
Kutipan 9. Percakapan Campur Kode JawaArab

Santri 1: "Cak, Ustad Darsono napa wonten?" (Apakah Pak Darsono ada?)

Santri 2: "Gak ngerti aku cak" (Tidak tahu)

Santri 1: "Jarene, Ustad iku paling galak cak?" (Katanya, Bapak itu galak?)

Santri 2: "Iyo Cak, Ustad Darsono iku mustahiq paling galak."

(Iya, beliau galak)

Berdasarkan kutipan 9, terlihat santri 1 beragumen bahwa Ustaz Darsono itu galak. Santri 2 pun merespon dengan meyakinkan dengan campur kode, yakni iku mustahiq paling galak. Hal tersebut mnunjukkan bahwa campur kode memiliki fungsi argumentatif dengan lebih meyakinkan.

Lebih persuasif, dapat dilihat pada kutipan berikut.

\section{Kutipan 10. Percakapan Campur Kode Persuasif \\ Santri 1: "Cak, sudah sholat? Bangun-bangun." \\ Santri 2: "Iya cak." \\ Santri 1: "Sudah jam 5 cak. Engko telat lho?" (Sudah jam 5. Nanti telat) \\ Santri 2: "Iya cak. Sebentar lagi cak" \\ Santri 1: "Yo wes ndang tangi gek sholat!" (ya sudah, cepet bangun dan sholat!)}

Berdasarkan kutipan 10, terlihat adanya campur kode persuasif. Hal tersebut terlihat ketika santri 1 mempengaruhi atau mengajak santri 2 untuk sholat shubuh. Santri 1 tidak langsung mengajak untuk sholat shubuh. Santri 1 mengawali dengan bertanya apakah sudah salat dan santri 2 pun langsung merespon dengan menjawab iya. Wujud persuasi juga nampak pada komunikasi berikutnya yakni ketika santri 1 memperingatkan bahwa sudah jam 5 dengan ditegaskan menggunakan campur kode engko telat. Terakhir santri 1 menegaskan dengan campur kode Yo wes ndang tangi gek sholat! Hal tersebut menunjukkan adanya campur kode dengan lebih persuasif. Dengan demikian campur kode memiliki fungsi lebih persuasif.

Berdasarkan kutipan 10 juga terlihat adanya nilai religius. Hal tersebut terlihat 
ketika santri mengajak santri lain untuk salat subuh yang merupakan kewajiban umat Islam. Hal terebut merupakan salah satu cara untuk meningkatkan pendidikan karakter santri. Iswatiningsih menjelaskan bahwa pendidikan karakter dilihat dari lia nilai utama yakni religius, nasionalis, mandiri, gotong royong, dan integritas (Iswatiningsih, 2019). Dengan demikian dalam komunikasi santri PPAH juga terdapat peningkatan nilai karakter santri.

Lebih singkat dan mudah diucapkan, dapat dilihat pada kutipan berikut.

Kutipan 11. Campur Kode Penyisipan Baster Santri 1: "Roan Jum'at bersih resik-resik kantor cak."

(Kerja bakti Jumat bersih bersih-bersih kantor.)

Santri 2: "Lho? Roan Jum'at bersih wis diumumne ta?"

(Kerja bakti Jum 'at bersih apakah sudah diumumkan?)

Santri 1: "Uwis Cak. Kamar A-9 resik-resik kantor ngarep."

(Sudah Cak. Kamar A-9 membersihkan kantor depan.)

Santri 2: "oww... enggeh cak."

(Iya Cak)

Berdasarkan kutipan 11, terlihat bahwa adanya campur kode membuat komunikasi lebih singkat dan mudah untuk diucapkan. Hal tersebut terlihat ketika santri 1 bertanya dengan campur kode "Roan". Roan merupakan kerja bakti yang biasa dilakukan setiap jumat pagi di PPAH. Santri 1 cukup dengan menggunakan istial Roan dan semua santri bisa memahami. Hal tersebut dibuktikan dengan tanggapan santri 2 bahwa Roan kamar A9 di kantor depan. Campur kode tersebut membuktikan bahwa campur kode memiliki fungsi lebih singkat dan lebih mudah diucapkan.

Berdasarkan kutipan 11 juga terlihat adanya budaya santri. Budaya santri terebut adalah budaya roan. Budaya-budaya tersebut perlu diperkenalkan kepada santri. Hal tersebut sesuai dengan pendapat Iswatiningsihyakni budaya kearifan lokal perlu dikenalkan dan diajarkan di sekolah agar menumbuhkan sikap cinta budaya (Iswatiningsih, 2019). Dengan demikian campur kode tersebut menunjukkan adanya penguatan penerapan budaya lokal dalam kehidupan santri.

Lebih sopan dan santun, dapat dilihat pada kutipan berikut.

\section{Kutipan 12. Campur Kode Penyisipan Frasa Santri 1: "Haflatul Imtihan mene a?" (Haflatul Imtihan besok ya?) Santri 2: "Enggeh cak. Yai Baidowi Muslich ngisi cak." \\ (Iya Cak. Kyai Baidowi Muslich hadir cak.)}

Berdasarkan kutipan 12, terlihat campur kode lebih sopan dan santun. Hal tersebut terlihat ketika Santri 2 merespon pertanyaan santri 1 dengan campur kode Enggeh. Enggeh merupakan salah satu kata krama inggil (paling halus) dalam bahasa Jawa. Padahal santri 1 sebelumnya bertanya dengan bahasa ngoko (kasar). Pemilihan kata Enggeh tersebut karena kata tersebut diikuti dengan Yai sesudahnya. Hal tersebut menunjukkan tingkat sopan dan santun secara tidak langsung. Walaupun Santri 2 tidak bertemu langsung dengan kiai tapi tetap menggunakan krama inggil (paling halus). Dengan demikian campur kode memiliki fungsi lebih sopan dan halus.

Berdasarkan kutipan 12 juga terlihat adanya nilai sopan-santun. Hal tersebut terlihat ketika santri menggunakan bahasa jawa halus atau krama inggil. Hal terebut merupakan salah satu cara untuk meningkatkan pendidikan karakter santri. Iswatiningsih menjelaskan bahwa mengimplementasikan pendidikan karakter berbasis kearifan lokal (Iswatiningsih, 2019). Dengan demikian dalam komunikasi santri PPAH muncul campur kode sebagai wujud implementasi sopan santun sebagai kearifan lokal bangsa Indonesia.

Lebih komunikatif, dapat dilihat pada kutipan berikut.

Kutipan 13. Percakapan Campur Kode Komunikatif

Santri 1: "Engko bengi jadwal diniyah apa?" 
(Nanti malam jadwal diniyah apa?)

Santri 2: "Kon iku. Mondok telung tahun ora apal-apal.“"

hafal)

(Kamu itu. sudah 3 tahun di pondok tidak

Santri 1: "aku kan santri teladan."

Santri 2: "Teladan apa telatan! Wayahe Ta'lim muta'alim cak."

(Jadwalnya kitab Ta'lim mutaalim)

Santri 1: "oh iya cak."

Berdasarkan kutipan 13, terlihat suasana komunikatif dan keakraban. Terlihat ketika Santri 1 bertanya jadwal diniyah. Jawaban santri 2 tidak langsung menjawab pertanyaan tersebut. Santri 2 mengejek dengan berkata mondok telung tahun ora apal-apal. Hal tersebut merupakan simbol keakraban di antara santri 1 dan santri 2. Simbol komunikatif pun juga terlihat dalam percakapan berikutnya, yakni ketika santri 1 berkata santri teladan dan santri 2 membalas teladan apa telatan. Dengan demikian campur kode memiliki fungsi lebih komunikatif.

Berdasarkan kutipan 13 juga terlihat adanya nilai dalam pendidikan. Hal tersebut terlihat ketika santri belajar kitab Ta'lim Mutaalim. Kitab tersebut merupakan kitab adab dalam pendidikan dan guru. Iswatiningsih menjelaskan bahwa budaya kearifan lokal perlu dikenalkan dan diajarkan di sekolah agar menumbuhkan sikap cinta budaya (Iswatiningsih, 2019). Dengan demikian dalam komunikasi santri PPAH muncul campur kode sebagai wujud pendidikan kearifan lokal untuk meningkatkan pendidikan karekter santri.

Campur kode memiliki beberapa fungsi. Berdasarkan paparan di atas, fungsi campur kode oleh santri PPAH meliputi (1) fungsi ketepatan makna atau rasa, (2) fungsi argumentatif, (3) fungsi persuasif, (4) fungsi singkat dan mudah diucapkan, (5) fungsi sopan dan santun, dan (6) fungsi komunikatif.

\section{Kesimpulan}

Berdasarkan hasil pembahasan dapat disimpulkan wujud campur kode yang meliputi (1) campur kode Jawa-Arab, (2) campur kode Indonesia-Jawa, (3) campur kode Jawa-Indonesia. Bentuk campur kode santri PPAH meliputi (1) bentuk penyisipan kata, (2) penyisipan bentuk frasa, (3) penyisipan bentuk ungkapan atau idiom, dan (4) penyisipan bentuk baster. Berdasarkan tipe campur kode di PPAH meliputi (1) campur kode ke dalam atau inner codemixing dan (2) campur kode ke luar atau outer code-mixing. Fungsi campur kode oleh santri PPAH meliputi (1) fungsi ketepatan makna atau rasa, (2) fungsi argumentatif, (3) fungsi persuasif, (4) fungsi singkat dan mudah diucapkan, (5) fungsi sopan dan santun, dan (6) fungsi lebih komunikatif.

\section{Daftar Pustaka}

Agustinuraida, I. (2017). Alih Kode dan Campur Kode dalam Tuturan Bahasa Indonesia oleh Mahasiswa Prodi Pendidikan Bahasa Indonesia Universitas Galuh Ciamis. Jurnal Diksatrasia, 1(2), 65-75. Retrieved from

https://jurnal.unigal.ac.id/index.php/ diksatrasia

Bintara, F. E., Saddhono, K., \& Purwadi, P. (2017). Alih Kode dan Campur Kode dalam Pembelajaran di Sekolah Menengah Pertama Kabupaten Gunung Kidul. Basastra: Jurnal Kajian Bahasa dan Sastra Indonesia, 5(1).

doi:https://doi.org/10.3329/dujl.v2i3. $\underline{4144}$

Chaer, A. (2006). Bentuk Campur Kode. Jakarta: Rineka Cipta.

Chaer, A., \& Agustina, L. (2010). Sosiolinguistik Perkenalan Awal. Jakarta: Rineka Cipta.

Chariri, A. (2009). Landasan Filsafat dan Metode Penelitian Kualitatif. Retrieved from Semarang:

Hapsari, N. R. (2018). Campur Kode dan Alih Kode dalam Video Youtube Bayu Skak. Jurnal Bapala, 2(5), 1-7. Retrieved from 
https://jurnalmahasiswa.unesa.ac.id/i ndex.php/bapala/

Horwae, D. (2018). Alih Kode dan Campur Kode dalam Tuturan Mahasiswa Patani di Yogyakarta. E-Journal Bahasa dan Sastra Indonesia, 7(4), 398-413. Retrieved from http://journal.student.uny.ac.id/ojs/in dex.php/bsi/article/view/11506/1105 $\underline{2}$

Isnaini, R. M. (2014). Penggunaan campur mode dalam komunikasi santri asrama Darussalam pondok pesantren Lirboyo kota Kediri. (Master Master Thesis), Universitas Islam Malang, Malang.

Iswatiningsih, D. (2019). Penguatan Pendidikan Karakter Berbasis NilaiNilai Kearifan Lokal di Sekolah. JURNAL SATWIKA, 3(2), 155-164. doi:https://doi.org/10.22219/SATWI KA.Vol3.No2.155-164

Keraf, G. (1984). Komposisi. Flores: Nusa Indah.

Kurniasih, D., \& Zuhriyah, S. A. (2017). Alih Kode dan Campur Kode di Pondok Pesantren Mahasiswa Darussalam. Indonesian Language Education and Literature (ILEAL), 3(1), 53-65. Retrieved from https://www.syekhnurjati.ac.id/jurnal lindex.php/jeill/article/view/1521/13 79

Kustriyono, E., \& Rochmat, M. C. (2016). Alih Kode dan Campur Kode Percakapan Mahasiswa di Perpustakaan Universitas Pekalongan. Jurnal Unikal, 4(1), 7$17 . \quad$ Retrieved from https://jurnal.unikal.ac.id/index.php/ pena/article/view/97/97

Mansur, A. K. (2013). Konsistensi Pendidikan Pesantren: Antara Mengikuti Perubahan dan Mempertahankan Tradisi. Jurnal
Islamic Review: Jurnal Riset Dan Kajian Keislaman, 2, 45-70.

Meldani, A. (2018). Alih Kode dan Campur Kode dalam Novel "The Sweet Sins" Karya Rangga Wirianto Putra. Jurnal Sapala, 5(1), 5-11. Retrieved from https://jurnalmahasiswa.unesa.ac.id/i ndex.php/jurnalsapala/article/view/22521/20638

Meyerhoff, M. (2007). Introducing Sociolinguistics. London: Routledge.

Murniati, M., \& Ariyani, F. (2015). Alih Kode dan Campur Kode pada Mahasiswa PBSI dan Implikasinya. Jurnal Kata (Bahasa, Sastra, dan Pembelajarannya), 3(5), 1-11. Retrieved from http://jurnal.fkip.unila.ac.id/index.ph p/BINDO1/article/view/9969/6728

Nababan, P. W. J. (1984). Sosiolinguistik Suatu Pengantar. Jakarta: Gramedia Pustaka Utama.

Nirmala, V. (2013). Alih Kode dan Campur Kode Tuturan Tukul Arwana pada Acara "Bukan Empat Mata". Jurnal Ranah, 2(2), 10-23. doi:https://doi.org/10.26499/rnh.v2i2 .232

Nugroho, A. (2011). Alih Kode dan Campur Kode pada Komunikasi Guru-Siswa di SMA Negeri 1 Wonosari Klaten. (Bachelor Bachelor Thesis), Universitas Negeri Yogyakarta, Yogyakarta. Retrieved from http://eprints.uny.ac.id/21918/1/Adi \%20Nugroho\%2007204241039.pdf

Rohmani, S., Fuady, A., \& Anindyarini, A. (2013). Analisis Alih Kode dan Campur Kode pada Novel Negeri 5 Menara Karya Ahmad Fuadi. BASASTRA: Jurnal Penelitian Bahasa, Sastra Indonesia dan Pengajarannya, 2(1), 1-16. Retrieved from http://jurnal.fkip.uns.ac.id/index.php/ 
bhs_indonesia/article/view/2149/156

$\underline{4}$

Saddhono, K. (2012). Kajian Sosiolingustik Pemakaian Bahasa Mahasiswa Asing dalam Pembelajaran Bahasa Indonesia untuk Penutur Asing (BIPA) di Universitas Sebelas Maret. Kajian Linguistik dan Sastra, 24(2), 176-186.

doi:https://doi.org/10.23917/kls.v24i $\underline{2.96}$

Saddhono, K., \& Rohmadi, M. (2014). A Sociolinguistics Study on the Use of the Javanese Language in the Learning Process in Primary Schools in Surakarta, Central Java, Indonesia. International Education Studies, 7(6), 25-30. doi: http://dx.doi.org/10.5539/ies.v7n6p2 $\underline{5}$

Simatupang, R. R., Rohmadi, M., \& Saddhono, K. (2018a). The Selection of the Language in Indonesian Learning at SMK Multi Karya Medan. HORTATORI: Jurnal Pendidikan Bahasa dan Sastra Indonesia, 2(1), 51-56. doi:https://doi.org/10.30998/jh.v2i1. $\underline{63}$

Simatupang, R. R., Rohmadi, M., \& Saddhono, K. (2018b). Tuturan dalam Pembelajaran Bahasa Indonesia (Kajian Sosiolinguistik Alih Kode dan Campur Kode). Kajian Linguistik dan Sastra, 3(2), 119-130.

doi:https://doi.org/10.23917/kls.v3i2. $\underline{5981}$

Sugiyono, S. (2011). Metode Penelitian Kuantitatif, Kualitatif, dan $R \& D$. Bandung: Alfabet.

Suwito, S. (1983). Pengantar Awal Sosiolinguistik Teori dan Praktik. Surakarta: Henary Offset. 